\title{
SURFACE MICROHARDENING STUDIES ON STEELS AFTER HIGH FEED MILLING
}

\author{
Jana Petrů', Tomáš Zlámal', František Špalek', Robert Čep ${ }^{1}$ \\ 1 VSB-Technical University of Ostrava, Faculty of Mechanical Engineering, 17. listopadu 2172/15, 708 00, \\ Ostrava Poruba, Czech Republic, e-mail: jana.petru@vsb.cz, tomas.zlamal@vsb.cz, frantisek.spalek@vsb.cz, \\ robert.cep@vsb.cz
}

Received: 2018.04 .15

Accepted: 2018.05.06

Published: 2018.06.01

\begin{abstract}
The paper deals with the impact of high-speed machining production methods on the integrity of component surfaces. One has to point out that cutting conditions during machining have a significant impact on the final properties of surface and subsurface layers of the workpiece. The conclusion summarizes and analyzes the achieved results of experimental activities on stainless austenitic steel 1.4301, hardened tool steel 1.2343 and high-speed steel 1. 3344 (ASP 2023). The results of the work experimental parts demonstrate the influence of cutting parameters on selected surface integrity ones, specifically strengthening the surface and subsurface layers. The performed experiments show that microhardness of a surface layer of the machined material can be influenced by suitable cutting conditions and other cutting process parameters.
\end{abstract}

Keywords: surface integrity, microhardness, high speed machining, microhardness.

\section{INTRODUCTION}

The term surface integrity descibes the state and attributes of a machined surface and its relationship to functional performace. In general, surface integrity can be divided into two aspects: first, the external topography of surfaces and second, the microstructure, mechanical properties and residual stresses of the internal subsurface layer. Surface integrity concerns not only the geometrical aspects of surfaces but rather the whole assemblage of their physical, mechanical, metallurgical, chemical and biological properties and characteristics [10]. When hardened materials are machined, however, the surface modification may occur because of rapid thermal working, resulting in metallurgical transformation and possible chemical interactions. The worked surface can exhibit a vastly different structure compared to that of the bulk of the material.

The cutting process affects the surface layer of the machined material by various physical, mechanical, and sometimes chemical processes.
Surface hardening is an external manifestation of plastic deformation and can be characterized as increased resistance of crystalline structure of the metal material to the movement of dislocations. The depth and intensity of hardening is mainly due to primary deformation zone, which may extend below the removed layer of the machined material, as well as tertiary deformation caused by the radius of the tool's cutting edge $[1,2,3,6,7]$.

Requirements for machined piece surface quality keep increasing; companies keep satisfying these needs in order to succeed on the market. They orient their attention to production methods that do not leave changes on surface or subsurface layers of machined pieces, and that are more powerful than the existing conventional production technologies. Leaders of these companies realize the necessity of innovations and use of progressive methods in a production cycle for competition purposes. For these companies the determining impetus for implementing of effective machining methods is the assortment of the machined parts and increasing pressure on quality 
and economy of production. Application of high speed machining brings new problems, but also significant financial effects caused by shortening of machine and secondary times, while increasing product quality.

Considering increased companies interest in analyses of surface quality parameters of machined parts, interest in questions of surface integrity studied in the presented work can be expected in the future. Thorough knowledge of surface integrity characteristics contributes to their proper implementation in practice. This work expands awareness of the necessity of orientation on surface quality monitoring and influence machining on surface and subsurface layers.

The introduction of high-speed machining technologies leads to a reduction in the depth and intensity of hardening of the machined material's surface layer. This is due to the narrowing of the primary deformation zone, which is thus focused only on the discharged splinters. This makes hardening depth very small. The measured values of surface microhardness as well as the hardening depth decrease with increasing cutting speed. The effect of the cutting speed on surface hardening also results from a reduction in time when the cutting force acts on the surface layer and an increase in the thermal output of machining. This issue was also dealt with by the authors in foreign publications $[4,5,9,11,12]$.

Hardening of the surface layer after machining depends on the properties of the material and deformation conditions. Most commonly, the hardening occurs in materials with lower initial strength, such as stainless austenitic steels. The surface of a material is hardened by deforming austenite to deformation martensite and by increasing the material strength. This subject has been already addressed in several specialized publications mainly related to the hardening of surface layers of these materials by shape cutting [13].

In the study [17], high-speed side milling experiments of $\mathrm{H} 13$ tool steel with coated carbide inserts were conducted under different cutting parameters. The microhardness and microstructure changes of the machined surface and subsurface were investigated. Instantaneous temperature distributions beneath the machined surface were analyzed under different cutting speeds and feed per tooth based on the model. It was found that the microhardness on the machined surface is much higher than that in the subsurface, which indicates that the surface materials experienced severe strain hardening induced by plastic deformation during the milling process. Furthermore, the hardness of machined surface decreases with the increase of cutting speed and feed per tooth due to thermal softening effects. Dry milling is a sustainable finishing process in mold manufacturing. This application of dry milling and influence on the surface integrity are shown in study [18].

\section{FORMATION OF SURFACE HARDENING AND SUBSURFACE MATERIAL LAYERS}

Hardening the surface of the machined material has a negative effect on tool life, contributing to the defective quality of the machined surface (formation of cracks, fissures, etc.) and subsurface metallurgical damage (recrystallization, residual stress). On the other hand, in terms of improving mechanical properties, the hardening of the surface layer of the machine components' material acts as a certain prevention against the formation of fatigue fracture. In some cases of finish machining, such as blasting, tumbling, roll burnishing and smoothing, the hardening of material surface is normal. When using these finishing operations, surface hardening leads to an increase in the surface resistance to wear, abrasion, corrosion, and other functional and mechanical properties of the surface.

Material hardening during machining occurs by the real cutting edge of the tool not being formed by a straight line, but by being a part of a cylindrical surface with a radius $r_{n}=5$ to 20 $\mu \mathrm{m}$. In these cases, interaction between the tool edge and the workpiece material leads to the occurrence of a negative rake angle. The negative rake angle makes the new surface of the part to be created by cutting as well as by moulding. Experimentally, there is an apparent functional dependence up to the value $r_{n}=0.2 \mathrm{~mm}$, up to which the depth of hardening and microhardness increase. After exceeding this value, the hardening depth increases more slowly and microhardness becomes stabilized. In addition to the radius of the tool edge, the intensity of hardening is also affected by the cutting speed and feed rate.

The rising value of the feed rate in relation to the edge wear also leads to an increase in the intensity of hardening. Its magnitude is partly affected by the depth of the cut, whose increase also increases hardening characteristics. The intensity of hardening of surface layers is also affected by the flank angle, tip radius and the geometry of the 
cutting edge already mentioned above. This phenomenon occurs especially in instruments worn on the flank. In the case of high-speed machining, the effect of the cutting depth is similar to its effect during conventional machining. Cutting depth affects the depth of hardening only within narrow limits; the characteristics of hardening increase with increasing cutting depth.

Flank angle $\alpha_{o}$ affects hardening only within certain limits. Increasing the flank angle $\alpha_{0}$ within $0^{\circ}$ to $8^{\circ}$ produces a sharp decline in the hardening depth. Beyond $8^{\circ}$ the dependence is no longer evident. The effect of the angle of the main edge $\kappa_{\mathrm{r}}$ on both studied characteristics of surface hardening is first increasing up to $\kappa_{\mathrm{r}}=45^{\circ}$, then decreasing [8].

\section{THE METHODOLOGY OF EXPERIMENTAL PART}

Tested materials were selected on the basis of the requirements of the practice. Machined material significantly influences the entire machining process. The most important properties of the refractory material are mechanical properties, chemical composition, thermal properties, the presence of inclusions, the tendency to mechanical strengthening, the structure of the material, etc. Tested materials in experimental part:
- Austenitic stainless steel $1.4301 \quad(340$, X5CrNi18-10) has excellent corrosion and oxidation resistance, with temperatures up to $350^{\circ} \mathrm{C}$. It is resistant to corrosion in a normal environment (water, weak alkalis, weak acids, industrial and city atmosphere). The high hardness of the material will make it more resistant to mechanical damage.

- Alloy steel 1.2343 (X38CrMoV5-1) - the material has been chosen for its high hardness, toughness, very good hot strength properties and for its use in practice. Steel is used for hot pressing tools and die casting molds, light metal processing tools, forging and die dies, scissors for shearing, etc. The material has been hardened to a hardness of $40 \pm 2$ HRC and $45 \pm 2$ HRC.

- High-speed steel 1.3344 (ASP 2023) - it is a high-speed steel made by powder metallurgy. Steel is suitable for use with high performance tools and for cold work. The material was delivered with a hardness of $260 \pm 2 \mathrm{HB}$. Table 1, 2 and 3 show the chemical composition of machined materials. The mechanical properties of the materials are shown in Table 4.

Material hardness is associated with the elastic and plastic properties of the material. The hardness of the tested material 1.4301 was 300 to 315 $\mathrm{HV}$, tool steel 1.2343 was hardened to 40 to 42

Table 1. Chemical composition of machined material 1.4301 (X5CrNi18-10)

\begin{tabular}{|c|c|c|c|c|c|c|c|c|}
\hline Content of elements & $\mathbf{C}$ & $\mathbf{S i}$ & $\mathbf{M n}$ & $\mathbf{P}$ & $\mathbf{N i}$ & $\mathbf{S}$ & $\mathbf{C r}$ & $\mathbf{N}$ \\
\hline$[\%]$ & 0.06 & 0.49 & 1.04 & 0.026 & $8.02 \div 10.5$ & 0.004 & $18.15 \div 0.05$ & 0.05 \\
\hline
\end{tabular}

Table 2. Chemical composition of machined materials 1.2343 (X38CrMoV5-1)

\begin{tabular}{|c|c|c|c|c|c|c|c|c|}
\hline Content of elements & $\mathbf{C}$ & Si & Mn & P max & S max & Cr & Mo & V \\
\hline$[\%]$ & $0.36 \div 0.42$ & $0.90 \div 1.20$ & $0.30 \div 0.50$ & 0.03 & 0.03 & $4.80 \div 5.50$ & $1.10 \div 1.40$ & $0.25 \div 0.50$ \\
\hline
\end{tabular}

Table 3. Chemical composition of machined materials 1.3344 (ASP 2023)

\begin{tabular}{|c|c|c|c|c|c|}
\hline Content of elements & C & Cr & Mo & W & V \\
\hline$[\%]$ & 1.30 & 4.20 & 5.00 & 6.40 & 3.10 \\
\hline
\end{tabular}

Table 4. Mechanical properties of machined materials

\begin{tabular}{|c|c|c|c|c|c|}
\hline $\begin{array}{c}\text { Mechanical properties } \\
\text { of machined materials }\end{array}$ & $\begin{array}{c}\mathbf{R}_{\mathrm{p} 0,2} \\
{[\mathrm{MPa}]}\end{array}$ & $\begin{array}{c}\mathbf{R}_{\mathbf{m}} \\
{[\mathrm{MPa}]}\end{array}$ & $\begin{array}{c}\mathbf{A 5} \\
{[\%]}\end{array}$ & $\begin{array}{c}\text { Hardness } \\
{[-]}\end{array}$ & $\begin{array}{c}\mathbf{E} \\
{[\mathrm{GPa}]}\end{array}$ \\
\hline 1.4301 (X5CrNi18-10) & 210 & $520 \div 720$ & 50 & $300 \div 315 \mathrm{HV}$ & 199 \\
\hline 1.3344 (ASP 2023) & 1290 & 490 & 40 & max. $300 \mathrm{HB}$ & 230 \\
\hline 1.2343 (X38CrMoV5-1) & 750 & $1150 \div 1380$ & $12-15$ & $40 \div 42 \mathrm{HRC}$ & - \\
\hline
\end{tabular}


Table 5. Calculated average values with uncertainty of measurement of microhardness HV 0.05 of the hardened layers of machined materials $1.4301,1.2343$ and 1.3344

\begin{tabular}{|c|c|c|c|c|c|}
\hline \multirow[b]{2}{*}{$\begin{array}{l}\text { Machined } \\
\text { material }\end{array}$} & \multirow[b]{2}{*}{$\begin{array}{l}\text { Catalogue designation } \\
\text { of the cutter used }\end{array}$} & \multicolumn{3}{|c|}{$\begin{array}{l}\text { Cutting parameters } \\
\text { of the experiment }\end{array}$} & \multirow[b]{2}{*}{$\begin{array}{c}\text { Microhardness HV } 0.05 \\
{[-]}\end{array}$} \\
\hline & & $\begin{array}{c}\text { Cutting speed } \\
v_{c} \\
{\left[\mathrm{~m} \cdot \mathrm{min}^{-1}\right]}\end{array}$ & $\begin{array}{c}\text { Feed per tooth } \\
\mathrm{f}_{z} \\
{[\mathrm{~mm}]}\end{array}$ & $\begin{array}{c}\text { Cutting depth } \\
a_{\mathrm{p}} \\
{[\mathrm{mm}]}\end{array}$ & \\
\hline 1.4301 & FF FWXD050-06-22-05 & 550 & 1 & 0.5 & $338 \pm 37.9$ \\
\hline 1.4301 & FF FWXD050-06-22-05 & 850 & 0.5 & 0.5 & $316 \pm 15.2$ \\
\hline 1.4301 & FF FWXD050-06-22-05 & 550 & 1.5 & 0.5 & $306 \pm 30.9$ \\
\hline 1.2343 & FF FW D50-22-06-C & 550 & 0.5 & 0.5 & $436 \pm 18.5$ \\
\hline 1.2343 & FF FW D50-22-06-C & 550 & 0.1 & 0.5 & $466 \pm 14.4$ \\
\hline 1.3344 & FF FW D50-22-06-C & 565 & 0.33 & 0.25 & $413 \pm 15.3$ \\
\hline 1.3344 & FF FW D50-22-06-C & 1131 & 0.33 & 0.25 & $368 \pm 18.4$ \\
\hline
\end{tabular}

HRC, which is equivalent to about $414 \mathrm{HV}$ according to ČSN EN ISO 18265:2013 Metallic materials - Conversion of hardness values. ASP 2023 is a high alloy high speed steel, manufactured powder metallurgically using the ASP Process. Material ASP 2023 is suitable for operations under extremely demanding conditions. It is a non cobalt grade for high performance cutting tools, cold work tools and rolls for cold rolling. Material ASP 2023 can be work as follows machining, polishing, plastic forming, electrical discharge machining, welding. Delivery hardness was supplied by soft annealed max. $260 \mathrm{HB}$. Heat in a protective atmosphere to $850-900^{\circ} \mathrm{C}$, hold for 3 hours, slow cool at $10^{\circ} \mathrm{C} / \mathrm{h}$ down to $700^{\circ} \mathrm{C}$, then air cooling.

For experiment the universal 5 axis $\mathrm{CNC}$ cutting center DMU60 MonoBlock ${ }^{\circledR}$ was used with the NC turntable from Germany. The spindle rpm range was $1 \div 24000 \mathrm{~min}^{-1}$. The DMU 60 MonoBlock ${ }^{\circledR}$ cutting center is one of highly productive machining tools with required accuracy. Table 5 shows calculated average values with uncertainty of microhardness measurement.

Measuring the changes in microhardness in the affected area of the surface provided specific data on the level and depth of hardening of the machined material surface. Microhardness tests are essentially similar to the static tests of macrohardness of the material. The difference is mainly in the loading forces. The tests were performed in the laboratories of the Faculty of Metallurgy and Materials Engineering, VŠB - Technical University of Ostrava. Microhardness was measured in accordance with ČSN EN ISO 6507-1, ČSN EN ISO 6507:2005 Metallic materials - Vickers hardness test - Part 1: Test method.
Microhardness was determined using the angular cut method. The method is suitable where hardening runs to small depths of subsurface layers. The actual distance of the indentation from the surface $h$ is calculated using a trigonometric function according to the formula $[4,5,14,16]$ :

$$
\mathrm{h}=\mathrm{h}_{\mathrm{z}} \cdot \cos \alpha(\mathrm{mm})
$$

Where: $h_{z}-$ the distance of indentation in the cut at angle $\alpha(\mathrm{mm}), \alpha-$ angle of angular cut to determine microhardness values $\left(^{\circ}\right)$.

Microhardness values were measured on an Emco-Test durometer. Each surface of the sample was subject to the measurement of 30 indentations and the resulting microhardness values were statistically processed, including the determination of measurement uncertainty. The complete findings of all uncertainty contributions cannot be quantified. The standard type A uncertainty has been determined by statistical analysis of repeated indentations into the test sample. Type B uncertainty has been determined based on experience of laboratory staff. When determining the intensity with which surface and subsurface layers of the machined material were hardened, three sets of control punctures were made, the most confirmative data being demonstrated by the measurement with HV 0.05 with a nominal value of test load of $0.4903 \mathrm{~N}$ and $0.045 \mathrm{~mm}$ increments between punctures.

\section{RESULTS OF MEASUREMENT AND EVALUATION OF MICROHARDNESS OF THE SURFACE AFTER MACHINING}

The punctures were made along $3.6 \mathrm{~mm}$ at an angle of $45^{\circ}$, to a depth of $3.5 \mathrm{~mm}$ perpendicularly to the machined surface, see Fig. 1, Fig. 2, Fig. 3, Fig. 4 and Fig. 5. 


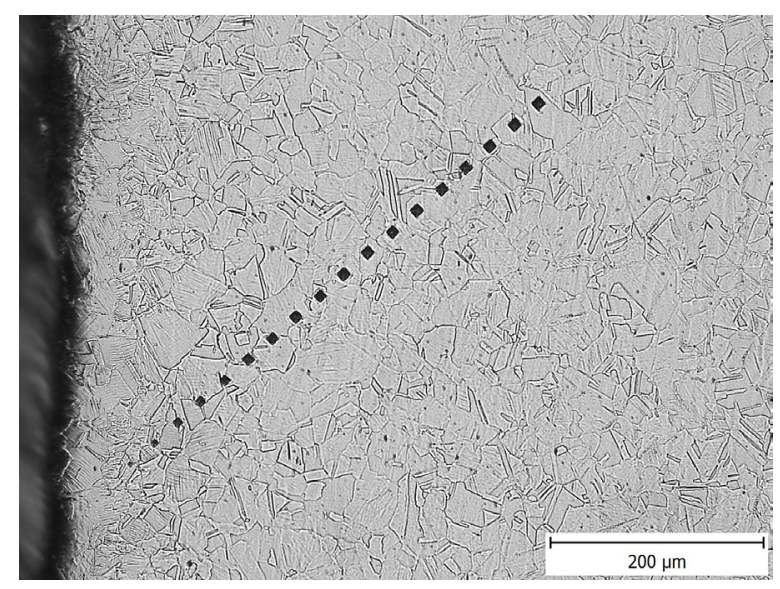

Fig. 1. Photograph of a transverse angular cut of the surface layer of stainless austenitic steel $1.4301\left(\mathrm{v}_{\mathrm{c}}=\right.$ $850 \mathrm{~m} \cdot \mathrm{min}^{-1}, \mathrm{f}_{\mathrm{z}}=0.5 \mathrm{~mm}, \mathrm{a}_{\mathrm{p}}=0.5 \mathrm{~mm}$ ) with distributed punctures during microhardness measurement

(200 x magnification)

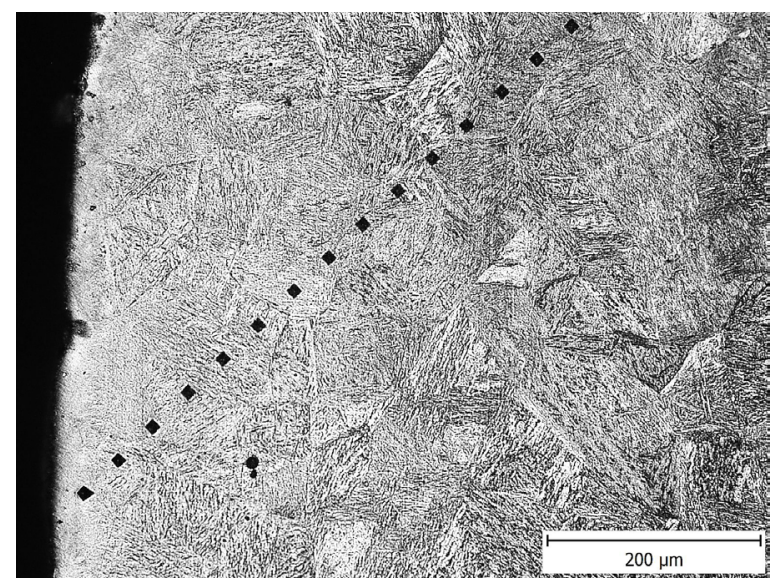

Fig. 2. Photograph of a transverse angular cut of the surface layer of hardened tool steel $1.2343\left(\mathrm{v}_{\mathrm{c}}=550\right.$ $\mathrm{m} \cdot \mathrm{min}^{-1}, \mathrm{f}_{\mathrm{z}}=0.5 \mathrm{~mm}, \mathrm{a}_{\mathrm{p}}=0.5 \mathrm{~mm}$ ) with distributed punctures during microhardness measurement (200 x magnification)

To verify the effect of machining at high cutting speeds on the hardening of surface, austenitic stainless steel 1.4301 and hardened tool steel 1.2343 have been deliberately chosen. In the case of the reference sample of austenitic steel 1.4301, increasing feed rate results in the hardness of the machined material increasing up to approximately $420 \mathrm{HV} 0.05$ at a cutting speed of $550 \mathrm{~m} \cdot \mathrm{min}^{-1}$ and feed per tooth of $1 \mathrm{~mm}$. When increasing the feed per tooth to 1.5 $\mathrm{mm}$ at the same cutting speed, substantial hardening of the machined surface is still achieved. Conversely, an increase in the cutting speed to $850 \mathrm{~m} \cdot \mathrm{min}^{-1}$ did not lead to any significant improvement.

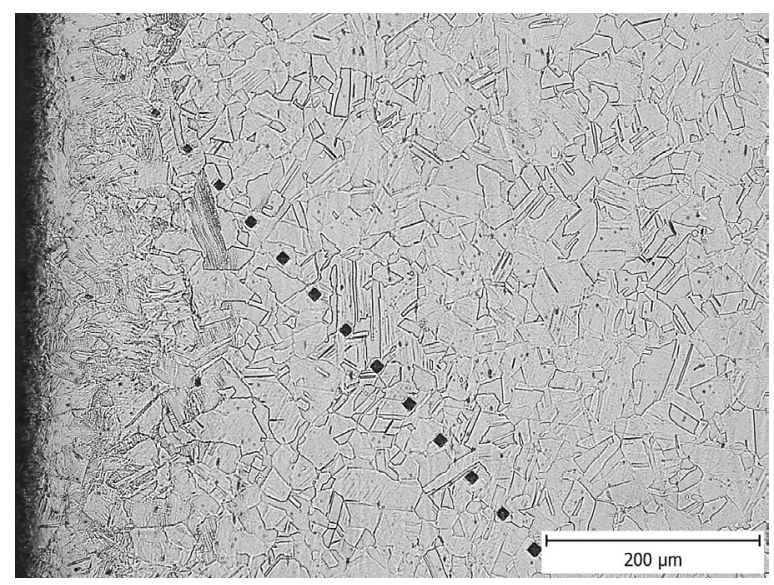

Fig. 3. Photograph of a transverse angular cut of the surface layer of stainless austenitic steel $1.4301\left(\mathrm{v}_{\mathrm{c}}=\right.$ $550 \mathrm{~m} \cdot \mathrm{min}^{-1}, \mathrm{f}_{\mathrm{z}}=1 \mathrm{~mm}, \mathrm{a}_{\mathrm{p}}=0.5 \mathrm{~mm}$ ) with distributed punctures during microhardness measurement $(200 \mathrm{x}$ magnification)

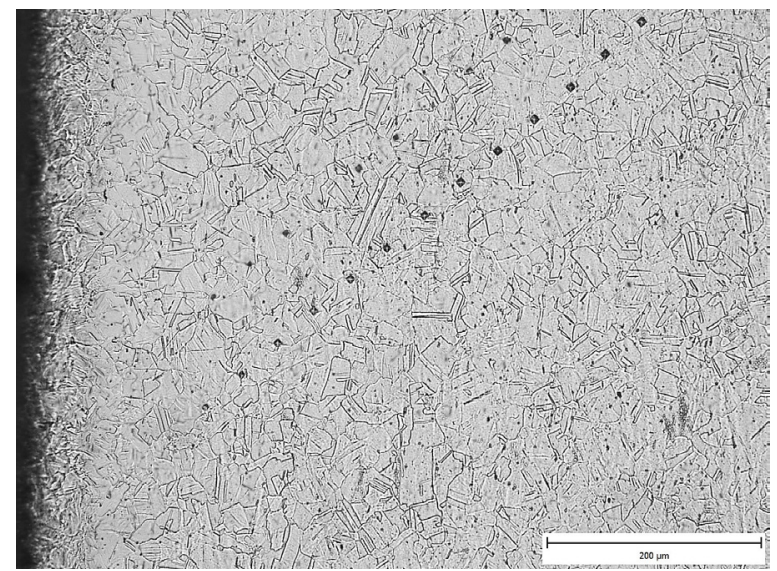

Fig. 4. Photograph of a transverse angular cut of the surface layer of stainless austenitic steel $1.4301\left(\mathrm{v}_{\mathrm{c}}=\right.$ $550 \mathrm{~m} \cdot \mathrm{min}^{-1}, \mathrm{f}_{\mathrm{z}}=1,5 \mathrm{~mm}, \mathrm{a}_{\mathrm{p}}=0.5 \mathrm{~mm}$ ) with distributed punctures during microhardness measurement

(200 x magnification)

The highest values of material hardening were achieved during milling at lower cutting speeds. Compared with the values in the material sheet of the tested steels, the values plotted in the graph are higher by several dozens. The values let us conclude that the intensity of hardening caused by machining led to a change in the microhardness of the surface layer of the material. With increasing microhardness, which also causes an increase in brittleness, we usually witness a disproportionate increase in residual stresses in connection with various processes that would be resolved by plastic deformation. 


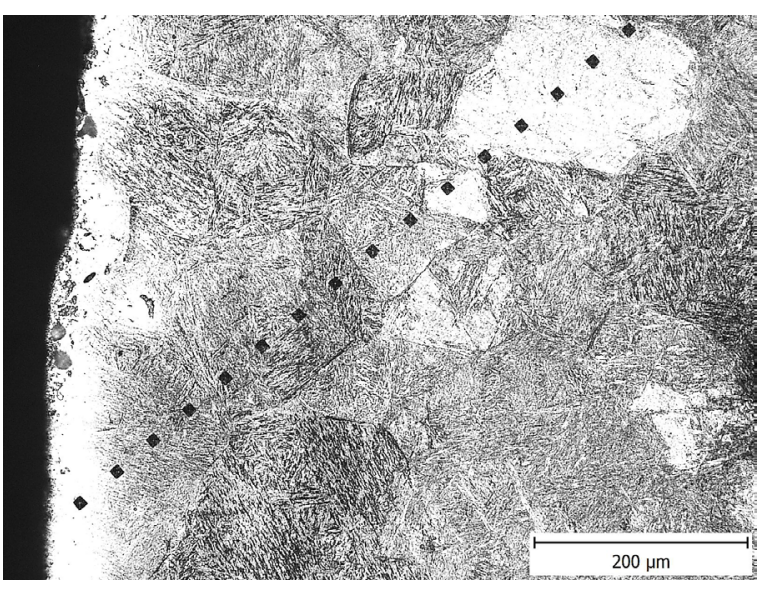

Fig. 5. Photograph of a transverse angular cut of the surface layer of hardened tool steel $1.2343\left(\mathrm{v}_{\mathrm{c}}=550\right.$ $\left.\mathrm{m} \cdot \mathrm{min}^{-1}, \mathrm{f}_{\mathrm{z}}=0.1 \mathrm{~mm}, \mathrm{a}_{\mathrm{p}}=0.5 \mathrm{~mm}\right)$ with distributed punctures during microhardness measurement $(200 \mathrm{x}$ magnification)

When increasing the cutting speed, the intensity of hardening is reduced.

The tested stainless austenitic steel 1.4301 is prone to hardening of the machined surface. Surface hardening leads to a rapid wear of the edge, undesirable breaking and the discharge of chips due to the chips becoming jammed in the profile grooves of tools. Low thermal conductivity causes plastic deformation of the cutting edge. The emerging build-up on the edge subsequently results in low quality of the machined surface. The chemical diffusion between the sur- face of the workpiece and the edge is another very negative type of wear. Due to this diffusion, cobalt binder is leached from the hard metal cutting material. The tool becomes subsequently damaged due to the cracking or chipping of the cutting edge. With regard to all of the adverse effects, for application to stainless steels the tools should ideally be optimised as a comprehensive system: cutting material - geometry - coating cutting parameters [15].

The high content of sulphur and selenium in these types of steels improves their machinability. Corrosion resistance is adversely affected by the presence of sulphides and care needs to be taken not to use them in places where their lower corrosion resistance may be detrimental. Stainless steels with high nickel content (e.g. 1.4303, $\mathrm{X} 4 \mathrm{CrNi18}$-12) have a reduced tendency for the hardness in the forming process, which means better properties after deep drawing. The higher nickel content in the steel (10 to 13\%) stabilizes the formation of austenitic steel, thus preventing the martensitic transformation.

The hardened layer after machining the material 1.2343 has not been positively proved. In the case of tool steel after heat treatment to the hardness of 40 to $42 \mathrm{HRC}$, the change in microhardness after machining was not expected. Hardening is more pronounced in mild steels.

Metallographic pattern of high-speed steel 1. 3344 (ASP 2023) after machining clearly shows different depths of hardened surface layers. The

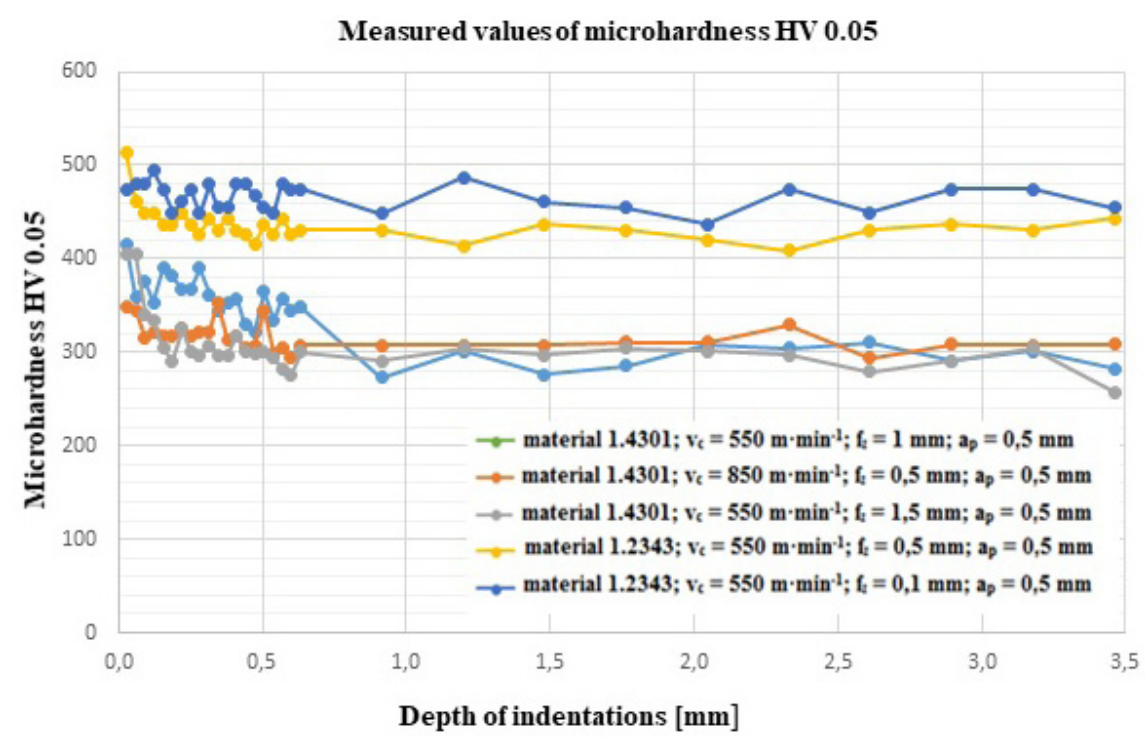

Fig. 6. Graphical representation of measured values of microhardness HV 0.05 of stainless austenitic steel 1.4301 and hardened tool steel 1.2343 


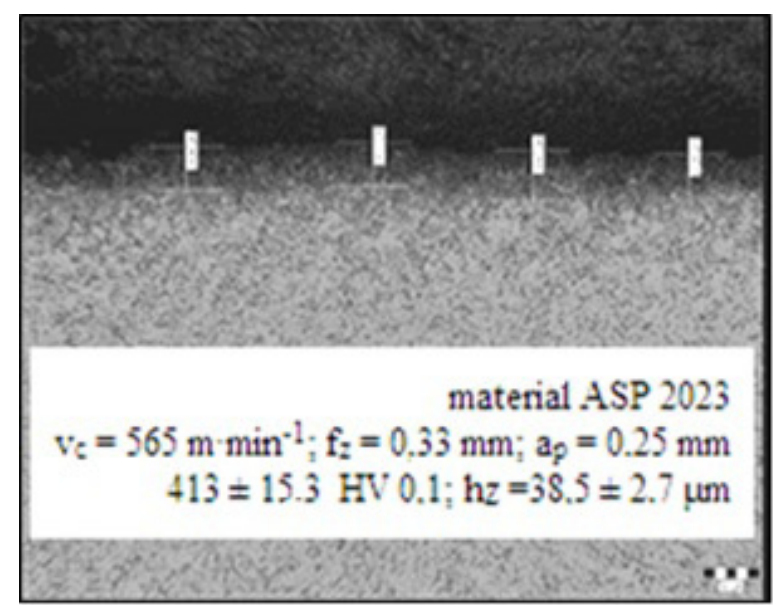

Fig. 7. Metallographic detail of the hardening of the material surface layer 1. 3344 (ASP 2023) after the machining with cutting parameters $\left(\mathrm{v}_{\mathrm{c}}=565 \mathrm{~m} \cdot \mathrm{min}^{-1}\right.$, $\left.\mathrm{f}_{\mathrm{z}}=0.33 \mathrm{~mm}, \mathrm{a}_{\mathrm{p}}=0.25 \mathrm{~mm}\right)(100 \mathrm{x}$ magnification, Nital etch $1 \%$ )

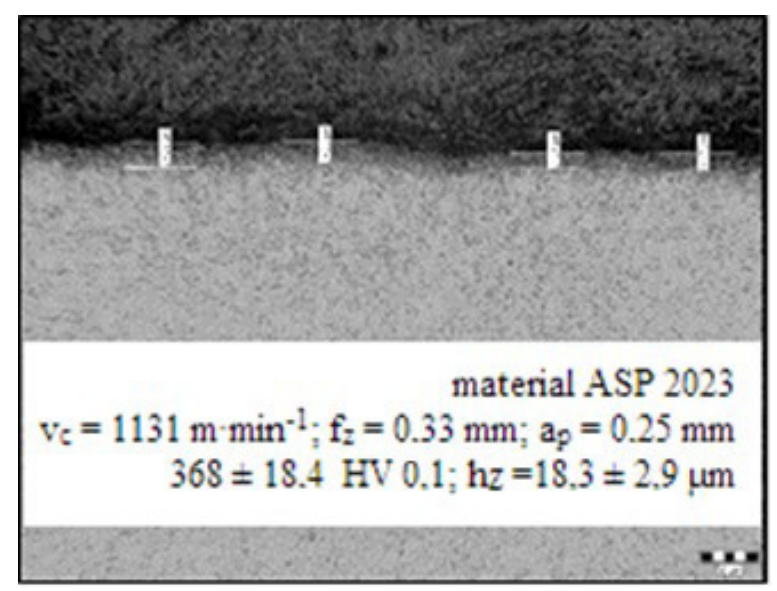

Fig. 8. Metallographic detail of the hardening of the material surface layer 1. 3344 (ASP 2023) after the machining with cutting parameters $\left(\mathrm{v}_{\mathrm{c}}=1131\right.$ $\left.\mathrm{m} \cdot \mathrm{min}^{-1}, \mathrm{f}_{\mathrm{z}}=0.33 \mathrm{~mm}, \mathrm{a}_{\mathrm{p}}=0.25 \mathrm{~mm}\right)(100 \mathrm{x}$ magnification, Nital etch 1\%)

depth of hardening of a specific machined steel decreases with increasing cutting speed, see Figure 7 . The pattern clearly shows densely excluded secondary carbides in fine tempered martensitic base material. The emergence of point carbides in the surface layer is the result of heating and deformation hardening of the material surface during the machining process.

The measured data can be affected by the test load applied, speed of movement of the penetrating sample, duration of the action of the test sample, vibration, temperature, surface condition of the sample, direction of the tested surface, fragility of the tested material, resolution of the microscope and the selected position of the indentation. The resulting microhardness depends on load more than is the case when measuring hardness at a load exceeding $10 \mathrm{~N}$. The speed of the penetrating sample must ensure that if reduced, the measured hardness does not change and, moreover, the required load must not be exceeded throughout the loading. The speed of the samples should typically not exceed $15 \mu \mathrm{m} \cdot \mathrm{s}^{-1}$. If the time of loading is less than $10 \mathrm{~s}$, the value of indentation may depend on the time, and the measured values will be too high and will not be in accordance with the required objective of measurement.

The effect of vibration is more pronounced at low loads. Generally, vibration leads to measuring lower microhardness. The effects of vibration and acoustic noise can be reduced by properly insulating the device from environmental influences. Another problem is to determine the distance of indentation of the penetrating sample from the surface in connection with surface roughness. Especially the resulting microhardness values are affected by sample preparation and sample surface condition; it is necessary to try to reduce localized heat or mechanical hardening which would affect the final microhardness values. When analysing measured data, account is taken of the value fluctuation with regard to anisotropy and metallographic structure of the material.

\section{CONCLUSION}

In practice surface quality of the machined piece is evaluated especially by its influence on functional properties of the parts. Condition and quality of the surface layer of the machined metal influence resistance to wear, fatigue strength, anti-corrosion stability, friction and fitting quality, etc. Thorough examination of all HSC process parameters will enable companies not only to apply this technology in the industrial practice, but especially to optimize the entire process.

The assumption of the experimental part of this work was that after exceeding a certain speed of cutting movement and speed beneficial effects of high cutting speed machining start to demonstrate themselves, and a strengthened material surface layer will not occur in such intensity and depth, as is the case when using conventional cutting parameters. The advantage of high speed machining is decreased amount of heat 
transferred into a machined part. The surface layer is less heat stressed, and the disadvantageous tensile stress that causes cracks at the machined part surface is eliminated. Lowering the surface temperature also eliminates structural changes in the surface layers.

We can state from the results of the presented work that after machining of 1.4301 corrosion resistant austenitic steel by the cutting parameters $\mathrm{v}_{\mathrm{c}}=550 \mathrm{~m} \cdot \mathrm{min}^{-1}, \mathrm{f}_{\mathrm{z}}=1 \mathrm{~mm}$, and $\mathrm{a}_{\mathrm{p}}=0.5 \mathrm{~mm}$, the machined piece surface layer has shown a higher micro strength than after machining by the cutting parameters $\mathrm{v}_{\mathrm{c}}=850 \mathrm{~m} \cdot \mathrm{min}^{-1}, \mathrm{f}_{\mathrm{z}}=0.5 \mathrm{~mm}$, and $\mathrm{a}_{\mathrm{p}}=0.5 \mathrm{~mm}$, with otherwise identical experiment parameters. The highest material strengthening values were achieved during frontal milling by lower cutting speeds. Strengthening of surface after machining was assumed at the austenitic corrosion resistant steel, since it is a steel prone to strengthening after machining by a cutting wedge.

A strengthened layer was not demonstrated with certainty after machining of 1.2343 tool steel heat treated to $40-42 \mathrm{HRC}$ hardness values. In general, strengthening is more significant in soft steels. On the contrary, after machining of 1.3344 (ASP 2023) steel different depths of strengthened surface layers are apparent on the metallographic section photography. The depth of strengthening of 1.3344 (ASP 2023) steel machined surface decreases with increasing cutting speed.

The performed experiments show that micro hardness of a surface layer of machined material can be influenced by suitable cutting conditions, tool geometry and other cutting process parameters. Surface hardening also influences quick wear of the cutting edge, unsuitable breakage and removal of splinters due to sticking to cutting tool profile channels. However, in many cases surface hardening is desirable; therefore, specific technical applications of produced parts need to be taken into account.

The results of the experiments imply that introduction of high-speed milling will result in significant time savings of the milling, and additional finishing of the machined surface will be eliminated with concurrent drop of production costs. Selection of suitable cutting conditions is the base for machined surface quality. The use of unsuitable production technologies or processes, cutting parameters, tool geometry, etc. can negatively reflect itself on decreased surface quality. Identification and measurement of qualitative and quantitative surface parameters contribute to finding actual status and functional properties of machined surface, and provide data for regulation of individual production process cutting parameters at the same time.

The analysis of surface layers must be understood in its complexity, and measured data need to be evaluated in comparison with other surface changes. It is apparent from our experiment results that use of progressive technologies in practice will save machine time and thus production costs. Of course, a necessary condition for success is to tie the production to a quality CAM system. Certainly another advantage is that the specified technologies are less ecologically demanding due to removal of processing liquids in order to lower temperatures at cutting locations.

The benefit of performed high speed cutting machining experiments is the possibility to use the work results by companies that machine similar industrial materials or companies that consider implementing these progressive technologies into production. A lot of companies that manage powerful machining centers do not use their potential in full. The use of existing capabilities of powerful cutting tools in combination with suitable clamps that damp vibrations is a condition for effective production process.

Thorough research of processes of highly productive production methods will allow companies both implementations of these technologies in industrial practice, and especially optimization processes. Structural equations and measures of dependency of surface roughness parameters on cutting movement speed and cutting speed for researched combinations of machining and machined materials were calculated by using experimental methods. These structural equations can help companies to select the first iteration of suitable cutting parameters.

The decisive moment for companies to introduce productive methods of milling is especially composition of their product portfolio and increasing stress on the quality and economy of production. Application of high-speed milling brings about new problems, but also significant financial effects due to shortening of machine and collateral times, while concurrently increasing product quality. In connection to globally increasing environmental and consequently legislative pressures it is suitable to emphasize the fact that progressive HSC leads to so-called environmentally clean technologies without use of process and lubrication liquids. 


\section{ACKNOWLEDGEMENT}

Article has been done in connection with projects Education system for personal resource of development and research in field of modern trend of surface engineering - surface integrity, reg. no. CZ.1.07/2.3.00/20.0037 financed by Structural Founds of Europe Union and from the means of state budget of the Czech Republic and by project Students Grant Competition SP2017/147 and SP2017/149 financed by the Ministry of Education, Youth and Sports and Faculty of Mechanical Engineering VŠB-Technical University of Ostrava. Experimental part of the work was performed in cooperation with the Institute of Mechanical Technology of Poznan University of Technology in Poland. The experimental activities took place during the research stay in Poznan within the CEEPUS program (Central European Exchange Programme for University Studies).

\section{REFERENCES}

1. Miller, T. Six points you must know about HighFeed Milling [online]. MMT MoldMaking technology. Available on WWW: <http://www. moldmakingtechnology.com/articles/six-pointsyou-must-know-about-high-feed-milling-> .

2. Schulz, H. Scientific Fundamentals of HSC. Munchen. C. Hanser V., 2001.

3. Kahles, J. S.; Field, M. New Quality Control Requirements for Integrity Surface. In ASM Materials Engineering Congress, 1972. Available on WWW: <http:// www.shotpeener.com/library/pdf/1972009.pdfs.

4. Field, M.; Kahles, F. Review of Surface Integrity of Machined Components, CIRP 2/1971, 153-163.

5. Stephenson, D. A.; Agapiou, J. S. Metal Cutting Teory and Practice. New York, Marcel Dekker, Inc., 1996, pp. 905.

6. Kováŕ, J. Ovlivnění kvality a jakosti obrobené plochy při frézování. In MM průmyslové spektrum. Praha, MM Publishing, s.r.o., 2004, 4, pp. 30.

7. Kř́ž, A. Integrita povrchu [online]. Available on WWW: <http://integrita.zcu.cz/download/skola2/ plzen_prez1.pdf>

8. Bátora, B.; Vasilko, V. Obrobené povrchy - technologická dedičnost', funkčnost'. Trenčín : Slovak Republic: Trenčínská Univerzita v Trenčíne v spolupráci s vydavatel'stvom GC Tech, 2000.

9. Davis, J. R. Surfaces Hardening of Steels: Understanding the Basics. Materials Park, OH: ASM International, 2002, pp. 346.

10. Davim, J. P. Surface integrity in machining. New York: Springer, 2010.

11. Whitehouse, D. J. Surface metrology. Measurement Science \& Technology, 1996, 955-972.

12. Vaněček, D. Experimentální výzkum vlivu vysokých řezných rychlostí na obráběcí proces se zaměřením na drsnost povrchu a zpevnění obrobené plochy prri frézování. Disertation thesis. ČVUT in Prague, 2005.

13. Dolinšek, S.; Suštaršič, B.; Kopač, J. Wear mechanisms of cutting tools in high-speed cutting processes [online]. In Wear 250. Elsevier, 2001. p. 349-356. Available on WWW: <http://www.ewp. rpi.edu/hartford/ ernesto/F2012/FWM/Papers/ Dolinsek2001-Wear-HSCutting.pdf $>$.

14. Neslušan, M.; Turek, S.; Brychta, J.; Čep, R.; Tabaček, M. Experimentálne metódy v trieskovom obrábaní. Žilina : Slovak Republic : EDIS Žilina, 2007, pp. 343.

15. Plánička, F. Efektivní frézování nerezových oceli [online]. In MM Průmyslové spektrum. Praha : MM publishing, s.r.o. Available on WWW: $<\mathrm{http}: / /$ www.mmspektrum.com/_clanek/efektivnifrezovani-nerezovych-oceli.html>.

16. ČSN EN ISO 6507-1, ČSN EN ISO 6507:2005 Metallic materials - Vickers hardness test - Part 1: Test method.

17. Wang, F.; Zhao, J.; Li, A.; Zhang, X. Effects of cutting conditions on microhardness and microstructure in high-speed milling of H13 tool steel International Journal of Advanced Manufacturing Technology. 2014. Vol. 73, 137-146, doi: 10.1007/ s00170-014-5812-9.

18. Li, W.; Guo, Y.; Guo, C. Superior surface integrity by sustainable dry hard milling and impact on fatigue [online]. CIRP Annals-Manufacturing Technology. 2013, Vol. 62, 567-570, doi: 10.1016/j. cirp.2013.03.024. 